\title{
Physiological changes in Mimosa caesalpiniifolia Benth. seeds from different sources and submitted to abiotic stresses
}

\author{
Eduardo C. Sousa ${ }^{1}$, Daniel V. Silva², Danielle M. M. Sousa ${ }^{1}$, Salvador B. Torres ${ }^{2} \&$ Renata R. T. Oliveira ${ }^{2}$ \\ ${ }^{1}$ Universidade Federal Rural do Semi-Árido/Programa de Pós-graduação em Ambiente, Tecnologia e Sociedade. Mossoró, RN. E-mail: educsousa@live.com - \\ ORCID: 0000-0002-9592-3435; daniellemariem@yahoo.com.br (Corresponding author) - ORCID: 0000-0002-4613-7155 \\ ${ }^{2}$ Universidade Federal Rural do Semi-Árido/Centro de Ciências Agrárias/Departamento de Ciências Agronômicas e Florestais. Mossoró, RN. E-mail: \\ daniel.valadao@ufersa.edu.br - ORCID: 0000-0003-0644-2849; sbtorres@ufersa.edu.br - ORCID: 0000-0003-0668-3327; renataramayanet@gmail.com \\ - ORCID: 0000-0002-7365-8271
}

\section{Key words:}

Fabaceae

'Sabiá'

PEG

$\mathrm{NaCl}$

abiotic stress

\begin{abstract}
A B S T R A C T
Seed germination of species that develop in arid and semi-arid soils can be altered by water deficit and abundance of salts in the soil. Knowledge on tolerance limits is fundamental to understand the adaptive capacity of species under such conditions. The objective of this study was to evaluate the physiological changes (germination and vigor) of Mimosa caesalpiniifolia seeds from different regions and submitted to water and saline stresses. To simulate water stress, the osmotic agent polyethylene glycol (PEG 6000) was adjusted to the potentials of $0,-0.2,-0.4,-0.6$ and $-0.8 \mathrm{MPa}$, whereas for the saline stress, $\mathrm{NaCl}$ solutions were adjusted to the potentials of $0,-0.1,-0.3,-0.5,-0.7 ;-0.9$ and $-1.1 \mathrm{MPa}$. The experimental design was completely randomized, in a $3 \times 5$ factorial scheme for water stress and $3 \times 7$ factorial scheme for saline stress, with four replicates of 25 seeds. The variables analysed were: germination, germination speed index and seedling shoot length, root length, shoot dry matter and root dry matter. M. caesalpiniifolia seeds, coming from different geographic regions, showed similar physiological responses to water stress; with respect to salt stress, their tolerance varies according to the region of harvest, and those from Vazante, MG, Brazil were more tolerant during germination and initial growth of seedlings.
\end{abstract}

\section{Palavras-chave: \\ Fabaceae \\ sabiá \\ PEG \\ $\mathrm{NaCl}$}

estresse abiótico

\section{Alterações fisiológicas em sementes de Mimosa caesalpiniifolia Benth. de diferentes procedências e submetidas aos estresses abióticos}

\section{R E S U M O}

A germinação de sementes de espécies que se desenvolvem em regiões áridas e semiáridas pode ser afetada por fatores como deficiência hídrica e excesso de sais no solo, desta forma, o conhecimento sobre os limites de tolerância a esses fatores, é fundamental para compreender a sua capacidade de adaptação. Objetivou-se neste trabalho avaliar as alterações fisiológicas (germinação e vigor) de sementes de Mimosa caesalpiniifolia provenientes de diferentes regiões brasileiras (Sudeste, Centro-Oeste e Nordeste) e submetidas aos estresses hídrico e salino. Para simular o estresse hídrico foi utilizado o agente osmótico polietilenoglicol (PEG 6000), ajustado para os potenciais de $0 ;-0,2 ;-0,4 ;-0,6$ e $-0,8 \mathrm{MPa}$, enquanto para o salino utilizou-se as soluções de $\mathrm{NaCl}$ nos potenciais de $0 ;-0,1 ;-0,3 ;-0,5 ;-0,7 ;-0,9 ;-1,1$ $\mathrm{MPa}$. O delineamento experimental foi inteiramente casualizado, em esquema fatorial $3 \times 5$ para estresse hídrico e 3 x 7 para estresse salino, com quatro repetições de 25 sementes. As variáveis analisadas foram: porcentagem de germinação, índice de velocidade de germinação, comprimento da parte aérea e da raiz e massa seca da parte aérea e da raiz de plântulas. As sementes de M. caesalpiniifolia, provenientes das diferentes regiões geográficas, respondem fisiologicamente de maneira semelhante ao estresse hídrico; já com relação ao estresse salino, a tolerância das sementes é variável em função da região de colheita, sendo as provenientes de Vazante, MG, mais tolerantes durante a germinação e o crescimento inicial das plântulas. 


\section{INTRODUCTION}

Mimosa caesalpiniifolia Benth., popularly known as 'sabiá, belonging to the Fabaceae family, is a forest species native to the Catinga biome (Lorenzi, 2008). It has potential to be used in agroecological activities, such as recovery of degraded areas, forage production and weed control (Lorenzi, 2008; Moura et al., 2011; Silva et al., 2015). M. caesalpiniifolia has been included in the list of vulnerable species of the World Conservation Monitoring Centre (IUCN, 2016), and is at high risk of extinction in the medium term due to its uncontrolled utilization as wood, firewood and charcoal, and to the loss and degradation of its habitat (IUCN, 2016).

Seeds of species that develop in soils of arid and semi-arid regions commonly find inadequate conditions for germination, as in the case of saline soils or soils with water deficit, abundant in these regions (Guedes et al., 2013). In this context, studies related to the germinative response of seeds subjected to conditions of artificial stresses constitute tools for a better understanding on the capacity of survival and adaptation of these species under conditions of natural stresses (Pereira et al., 2012).

The study on seeds from different geographic regions consists in finding the phenotypical differences determined by the environmental variations. Thus, despite belonging to the same species, in each locality the seeds are subject to variations of temperature, day length, rainfall levels and other factors which eventually highlight certain aspects of their genetic composition, i.e., the environment may be adequate for the expression of certain features that, in another site, would not be manifested. By studying different sites of origin, it is possible to capture various expressions of the genotype, allowed by the adequate environmental conditions (Botezelli, 2000).

Considering the water restriction and abundance of saline soils, characteristics inherent to arid and semi-arid regions such as the Caatinga biome, this study aimed to evaluate physiological alterations (germination and vigor) of $M$. caesalpiniifolia seeds from different regions subjected to water and saline stresses.

\section{Material AND Methods}

The experiments were carried out from June to September 2016, at the Laboratory of Seed Analysis of the Federal Rural University of the Semi-Arid Region (UFERSA), Campus Mossoró, RN, Brazil. The experiment used M. caesalpiniifolia seeds from 20 trees with good seed production and good phytosanitary aspect, located in different geographic regions, whose climates were all classified as Aw according to the Köppen-Geiger classification, namely: Luziânia, GO (16 $16^{\circ}$ 09” S; 47 57' 01" W; $930 \mathrm{~m}$ ), with mean temperature of $21.1^{\circ} \mathrm{C}$, relative air humidity of $87 \%$ and mean annual rainfall of 1,515 mm; Vazante, MG (17 59’ 13” S; 46 54’ 28” W; 680 m), mean temperature of $23.5^{\circ} \mathrm{C}$, relative air humidity of $70 \%$ and mean annual rainfall of $1,631 \mathrm{~mm}$; and Montanhas, RN $\left(06^{\circ}\right.$ 29' $09^{\prime \prime} \mathrm{S} ; 35^{\circ} 17^{\prime} 15^{\prime \prime} \mathrm{W} ; 87 \mathrm{~m}$ ), mean temperature of $25.5^{\circ} \mathrm{C}$, relative air humidity of $65 \%$ and mean annual rainfall of 1,008 $\mathrm{mm}$, collected in March, April and May 2016, respectively.
Treatments were arranged in a completely randomized design, in a $3 \times 5$ factorial scheme (three regions $\mathrm{x}$ five osmotic potentials) in the tests with PEG, and in a $3 \times 7$ factorial scheme (three regions $\mathrm{x}$ seven osmotic potentials) in the simulations with sodium chloride $(\mathrm{NaCl})$ solutions, with four replicates of 25 seeds in each treatment.

Before installing the experiment, seeds were sanitized through immersion for $10 \mathrm{~min}$ in solution containing 5 drops of neutral detergent in $100 \mathrm{~mL}$ of water, followed by rinse in running water until full removal of the product. Seed dormancy was broken by a cut on the side of the upper third, region opposite to the micropyle (Brasil, 2013), and then the seeds were stored in controlled environment $\left(18-20{ }^{\circ} \mathrm{C}\right.$ and $50 \%$ relative air humidity) until the beginning of the experiment.

Water stress was simulated using the osmotic agent polyethylene glycol (PEG 6000), adjusted to osmotic potentials of $0,-0.2,-0.4,-0.6$ and $-0.8 \mathrm{MPa}$. Saline stress was simulated using sodium chloride $(\mathrm{NaCl})$ solutions, calibrated for the osmotic potentials of $0,-0.1,-0.3,-0.5,-0.7,-0.9,-1.1 \mathrm{MPa}$. PEG 600 solutions were prepared according to Vilella et al. (1991), whereas $\mathrm{NaCl}$ solutions were prepared using the Van't Hoff formula (Eq. 1) (Salysbury \& Ross, 1992).

$$
\Psi \text { os }=\text { CiRT }
$$

where:

Yos - osmotic potential, atm;

C - concentration, $\mathrm{mol} \mathrm{L}^{-1}$;

i - isotonic coefficient;

$\mathrm{R}$ - universal gas constant, $0.082 \mathrm{~atm} \mathrm{~mol}^{-1} \mathrm{o} \mathrm{K}^{-1}$; and,

$\mathrm{T}$ - temperature, ${ }^{\circ} \mathrm{C}$.

Sowing was performed in paper roll substrate, maintained in germinator at $25^{\circ} \mathrm{C}$. The paper was soaked in distilled water (control) and, for each treatment, in the solutions corresponding to the different osmotic potentials and saline concentrations, in the amount of 2.5 times its dry weight.

The evaluations were daily carried out until 10 days after sowing (DAS) (Brasil, 2013). Treatments were evaluated based on the following variables: a) Germination - calculated according to Brasil (2013), considering as germinated seeds with radicle length equal to or longer than $5 \mathrm{~mm}$; b) Germination speed index - determined by daily recording the number of germinated seeds until 10 DAS and calculating the index using the equation proposed by Maguire (1962); c) Seedling shoot and root lengths - based on the means of measurements of all normal seedlings (Brasil, 2013) in each treatment. Shoot length was measured from the base to the apex of the apical meristem, whereas root length was measured from the base to the tip of the root, and the results were expressed in $\mathrm{cm}$; d) Seedling shoot and root dry matters - all normal seedlings of each treatment were separated into shoots and roots and taken to a forced-air oven at temperature of $65^{\circ} \mathrm{C}$, for $48 \mathrm{~h}$ until constant weight, and the results were expressed in mg seedling ${ }^{-1}$.

The data were subjected to analysis of variance by $\mathrm{F}$ test, and follow-up analysis of the factors when there was significant effect of interaction. Means referring to the effects of the 
potentials were subjected to regression analysis, adopting linear and polynomial regression models with significance level lower than 0.05 and highest order $\left(\mathrm{R}^{2}\right)$, thus using the equation that fitted best to the data. In addition, means relative to the origins of the seeds were evaluated by Tukey test $(\mathrm{p}<0.05)$. The statistical analyses were carried out using the statistical program Assistat version 7.7 (Silva \& Azevedo, 2016).

\section{Results AND Discussion}

The results of the analysis of variance for the interaction between the factors origins and levels, as well as the isolated effect of these factors, are presented in Table 1. Except for germination $(p>0.05)$, the interaction between factors had significant effect on the other variables, at 0.01 probability level for germination speed index, shoot length, root length and root dry matter, and at 0.05 probability level for shoot dry matter.

When PEG was used to simulate the stress, the germination of seeds from different regions of collection decreased as the osmotic potential decreased, and there was no germination at -0.8 MPa (Figure 1A).

Regarding the effect of saline stress on germination, it was observed that for the three regions of collection, the data fitted to quadratic models and highest values occurred at the

Table 1. Summary of analysis of variance for germination (G), germination speed index (GSI), seedling shoot length $(\mathrm{SL})$, seedling root length $(\mathrm{RL})$, seedling shoot dry matter (SDM), seedling root dry matter (RDM) relative to Mimosa caesalpiniifolia Benth. seeds as a function of origin and levels of water and saline stresses

\begin{tabular}{|c|c|c|c|c|c|c|c|}
\hline SV & $\overline{D F}$ & $\bar{G}$ & GSI & $\overline{S L}$ & $\overline{\mathrm{RL}}$ & SDM & RDM \\
\hline & \multicolumn{7}{|c|}{ Polyethylene glycol (PEG) } \\
\hline Origins (0) & 2 & $1.2319 \mathrm{~ns}$ & 6.9489 ** & 14.2775 ** & 6.4835 ** & 6.3324 ** & $29.6687 * *$ \\
\hline Levels (L) & 4 & 664.4633 ** & $1471.0745^{* *}$ & 969.1265 ** & 219.2284 ** & 209.4668 ** & $208.3801^{* *}$ \\
\hline $0 \times L$ & 8 & $1.6947^{\mathrm{ns}}$ & 4.6433 ** & 6.3565 ** & $4.2037 * \star$ & 2.1814 * & 4.1365 ** \\
\hline \multirow[t]{2}{*}{ CV (\%) } & - & 10.80 & 9.04 & 11.97 & 17.95 & 17.96 & 16.39 \\
\hline & \multicolumn{7}{|c|}{ Sodium chloride (NaCl) } \\
\hline Origins (0) & 2 & $7.982^{\star \star}$ & $20.344^{* *}$ & $40.216^{\star \star}$ & $4.657^{\star}$ & 59.900 ** & $16.010 * \star$ \\
\hline Levels (L) & 6 & $88.883^{\star \star}$ & $314.943^{\star \star}$ & $306.274^{\star \star}$ & $52.209 * *$ & $55.045^{\star \star}$ & $8.278^{\star \star}$ \\
\hline $0 \times L$ & 12 & $2.163^{*}$ & 2.462 * & 3.701 ** & $4.515^{\star \star}$ & $3.322^{\star \star}$ & $4.061^{\star \star}$ \\
\hline CV (\%) & - & 11.20 & 10.24 & 11.53 & 24.59 & 16.34 & 30.82 \\
\hline
\end{tabular}

${ }^{n}$ Not significant; **Significant at 0.01 probability level; * Significant at 0.05 probability level; SV - Source of variation; DF - Degrees of freedom; $0 \times$ L - Interaction between origins and levels; CV - Experimental coefficient of variation

A.

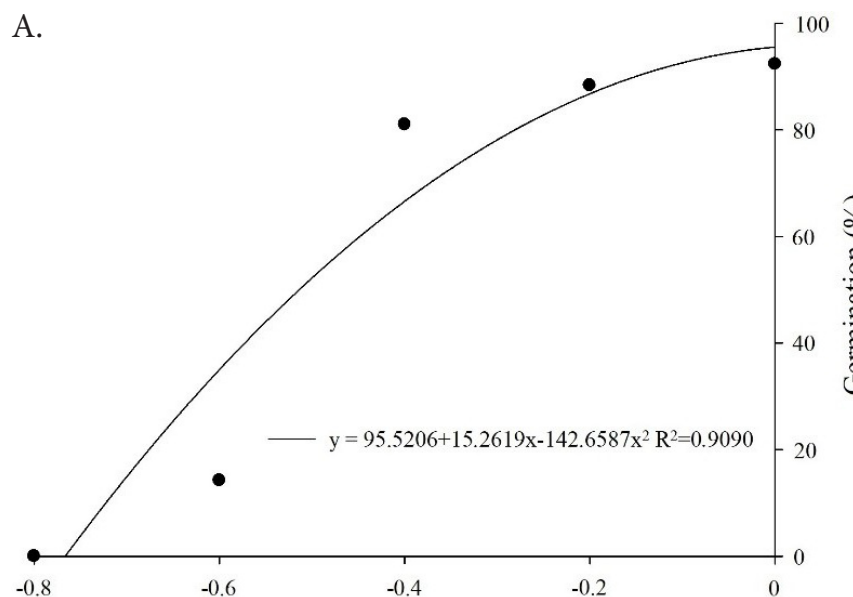

C.

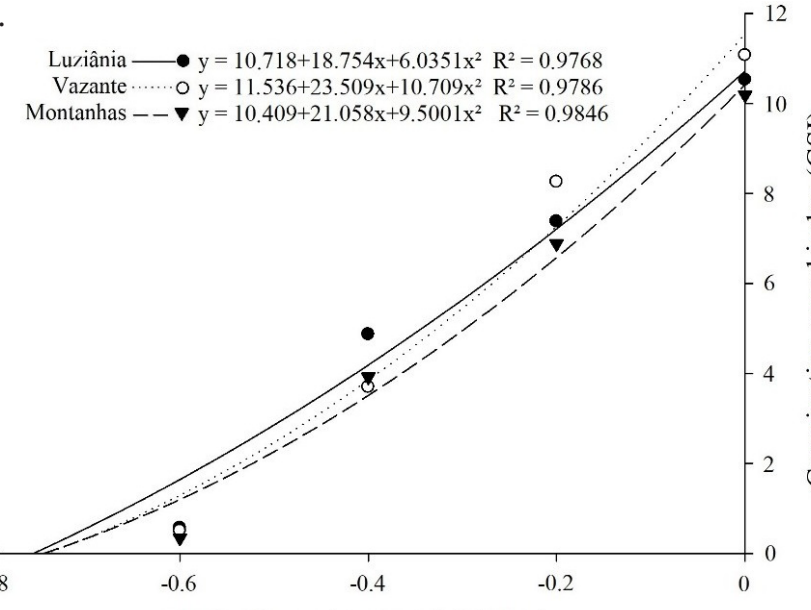

PEG - Osmotic potential (MPa)
B.

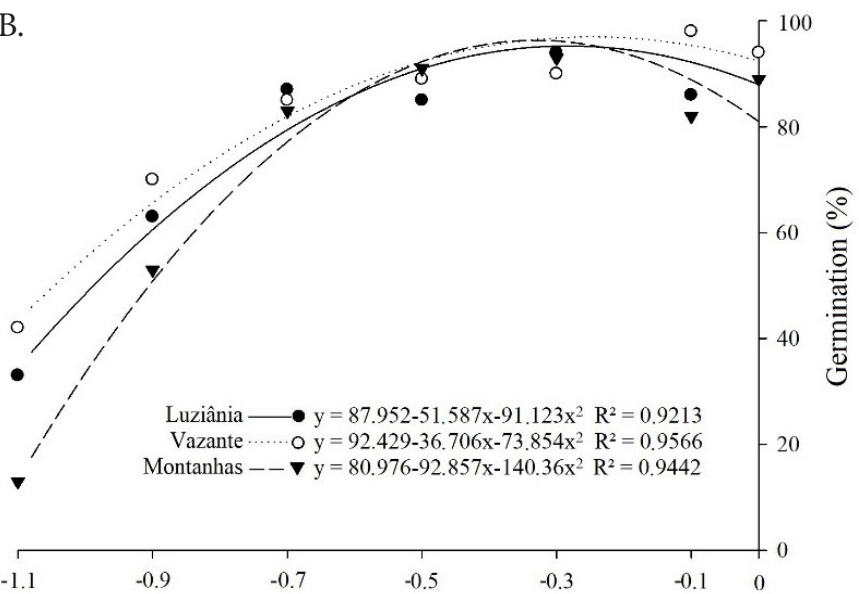

$\begin{aligned} \text { Duziânia } \longrightarrow \mathrm{y} & =9.7529+2.777 \mathrm{x}-4.5813 \mathrm{x}^{2} \mathrm{R}^{2}=0.9356 \\ \text { Vazante } \cdots \ldots . \mathrm{y} & =10.635+5.4402 \mathrm{x}-2.5055 \mathrm{x}^{2} \mathrm{R}^{2}=0.9757 \\ \text { Montanhas }--\mathrm{y} y & =9.3816+3.4237 \mathrm{x}-4.6143 \mathrm{x}^{2} \mathrm{R}^{2}=0.9385\end{aligned}$ Montanhas - $-\mathbf{\nabla} y=9.3816+3.4237 \mathrm{x}-4.6143 \mathrm{x}^{2} \quad \mathrm{R}^{2}=0.938$

Figure 1. Germination and germination speed index of Mimosa caesalpiniifolia Benth. seeds as a function of different levels of water stress (A and C) and saline stress (B and D) 
potentials $-0.28,-0.25$ and $-0.33 \mathrm{MPa}$, with germination of 95.2, 96.9 and 96.3\%, for seeds collected in Luziânia, Vazante and Montanhas, respectively. Besides, at the lowest osmotic potential, the germination of seeds from Montanhas was the most affected (Figure 1B).

For PEG, Moura et al. (2011) observed significant reduction in the germination of $M$. caesalpiniifolia seeds at the osmotic potential of $-0.5 \mathrm{MPa}$, different from the data in the present study, in which the reduction of germination was more accentuated at potentials below - $0.5 \mathrm{MPa}$. Water restriction simulated using PEG also reduced germination in other species native to the Caatinga biome, such as Mimosa tenuiflora (Willd) Poir. (Bakke et al., 2006); Zizyphus joazeiro Mart. (Lima \& Torres, 2009); Amburana cearensis (Allemão) A.C. Smith (Almeida et al., 2014); Poincianella pyramidalis (Tul.) L.P. Queiroz and Anadenanthera colubrina (Vell.) Brenan (Santos et al., 2016); Piptadenia moniliformis Benth. (Azerêdo et al., 2016); and Chorisia glaziovii O. Kuntze (Silva et al., 2016).

For both agents tested (PEG and $\mathrm{NaCl}$ ), the germination speed index (GSI) decreased as the potentials decreased, regardless of seed origin (Figure $1 \mathrm{C}$ and D), obtaining satisfactory results until the potentials of $-0.2 \mathrm{MPa}$ with PEG and -0.5 MPa with $\mathrm{NaCl}$.

In studies about water stress on germination, Santos et al. (2016) found inhibition of germination, with GSI equal to zero, at the osmotic potential -1.2 MPa (PEG) in seeds of 'angico' (Anadenanthera colubrina (Vell.) Brenan) and 'catingueira' (Poincianella pyramidalis (Tul.) LP Queiroz). Ribeiro et al. (2008) and Barreto et al. (2010), observed influence of saline stress on germination and initial growth of $M$. caesalpiniifolia seedlings, as well as reduction in GSI as salinity increased.

The effect of water restriction and salinity on germination and germination speed index may have been due to the increase in substrate osmotic retention, hampering water absorption by seeds and, consequently, compromising the processes of cell division and elongation, besides the mobilization of reserves essential to germination, thus reducing both final germination and its speed (Nasr et al., 2012).

The shoot length of $M$. caesalpiniifolia seedlings decreased with the reduction of osmotic potential, due to the increase

A.

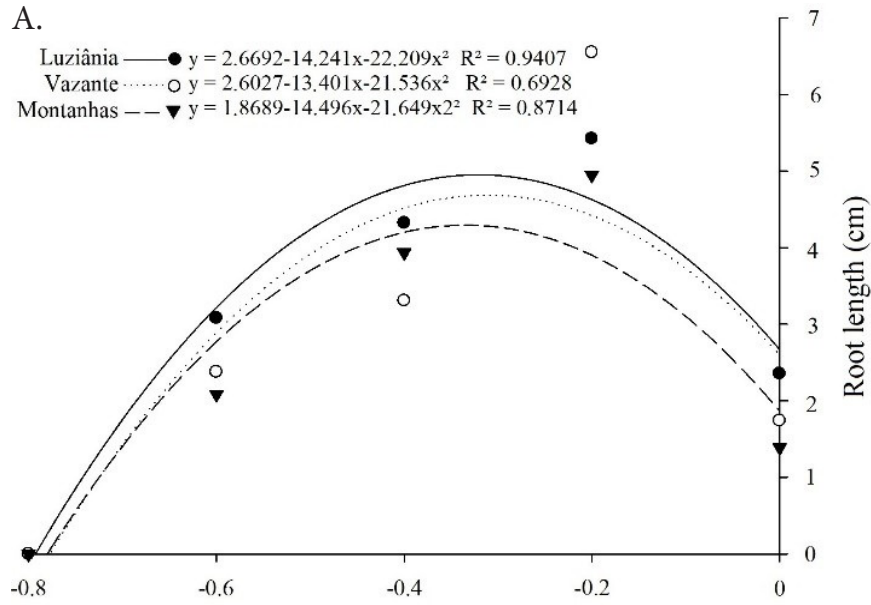

PEG - Osmotic potential (MPa)

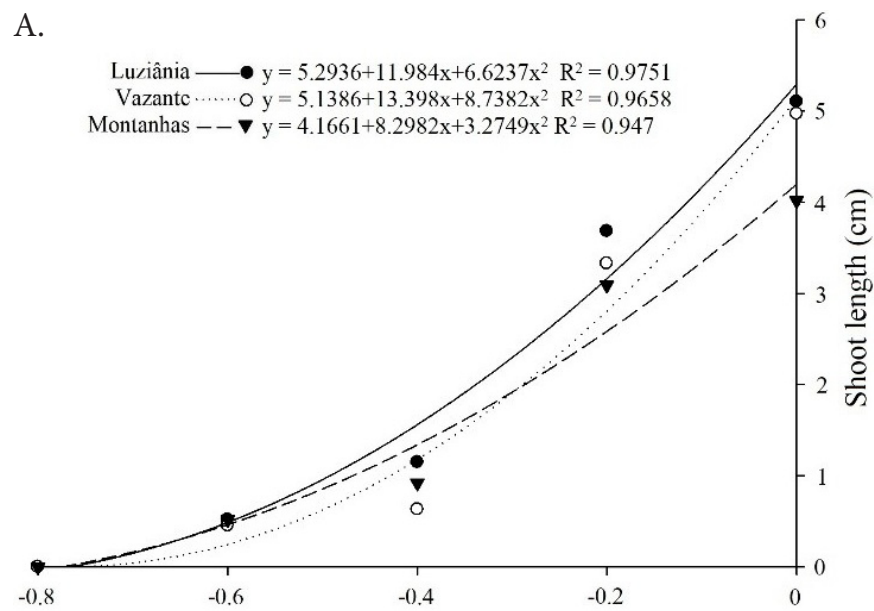

PEG - Osmotic potential (MPa)

B.

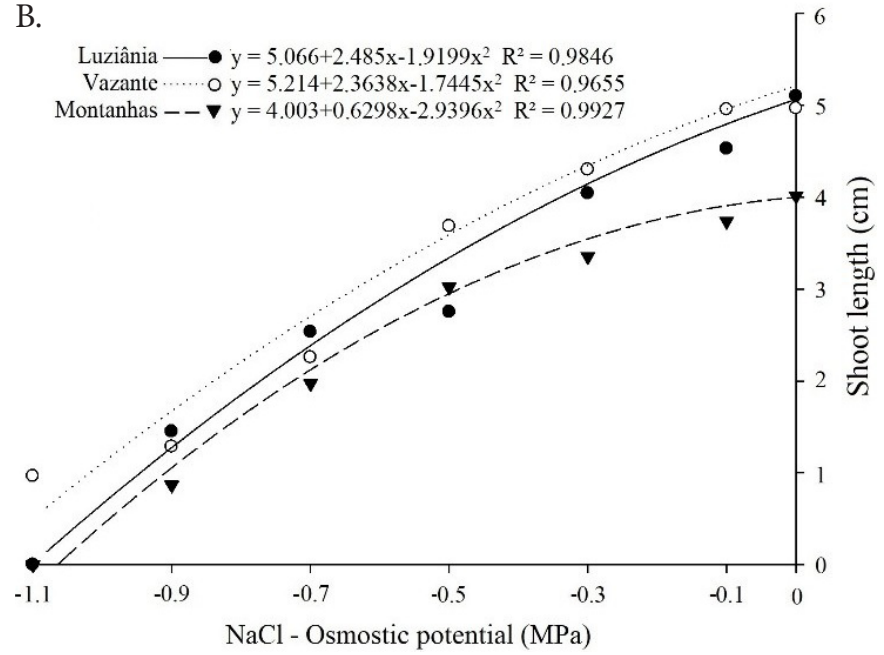

Figure 2. Shoot length of Mimosa caesalpiniifolia Benth. seedlings as a function of different levels of water stress (A) and saline stress (B)

in water stress (Figure 2A) and with the increment in salinity (Figure $2 \mathrm{~B}$ ), regardless of seed collection region.

Water stress influenced seedling root length and the maximum values were estimated around the potential of $-0.3 \mathrm{MPa}$ for the three regions of collection, 4.94, 4.68 and $4.27 \mathrm{~cm}$, for seeds from Luziânia, Vazante and Montanhas, respectively, which showed decreasing values at more negative potentials (Figure $3 \mathrm{~A}$ ).

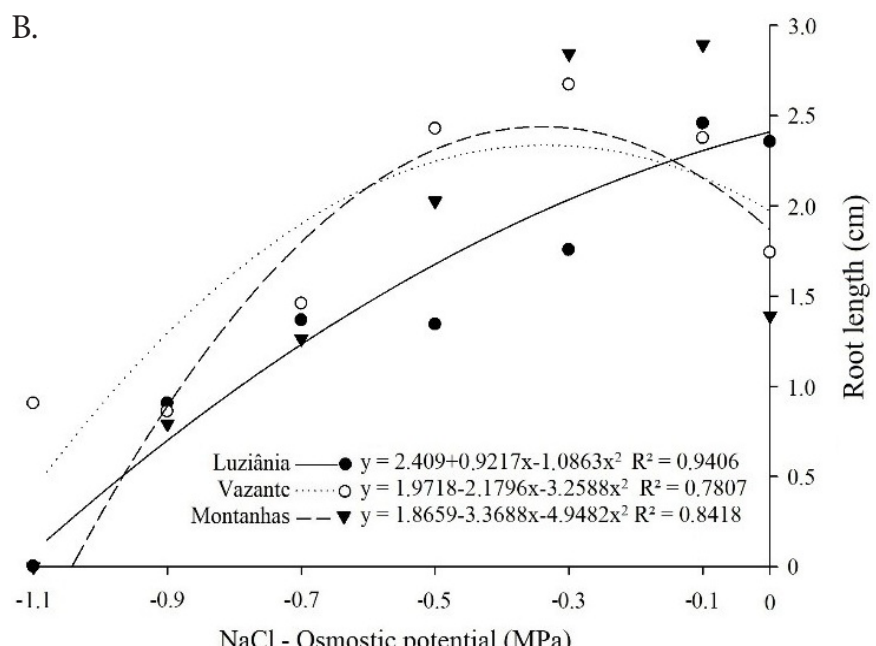

Figure 3. Root length of Mimosa caesalpiniifolia Benth. seedlings as a function of different levels of water stress (A) and saline stress (B) 
In the saline stress, highest values of root length were found at the potential of $-0.1 \mathrm{MPa}$ in seedlings from seeds collected in the three localities, equal to $2.49,1.72$ and $1.47 \mathrm{~cm}$, respectively, for Luziânia, Vazante and Montanhas, and these values decreased until the potential of -1.1 MPa. In addition, seeds from Luziânia showed higher sensitivity to saline stress for this variable (Figure 3B).

Under conditions of water or saline stress, the first effect measurable on the seedlings is precisely the decline of growth caused by the reduction in cell expansion, which needs adequate turgor (Taiz \& Zeiger, 2013).

Reduction in seedling growth due to water restriction has been reported in other studies with species native to the Caatinga, such as Zizyphus joazeiro Mart. (Lima \& Torres, 2009), Amburana cearensis (Allemão) A.C. Smith (Almeida et al., 2014) and Chorisia glaziovii O. Kuntze (Silva et al., 2016). Likewise, studying the tolerance of M. caesalpiniifolia to salinity, Ribeiro et al. (2008) observed significant reduction in seedling height due to the increase in electrical conductivity.

Seedling shoot dry matter also decreased for the seeds collected in the three regions, due to the increase of both water restriction and salinity (Figures $4 \mathrm{~A}$ and $\mathrm{B}$ ).

Water stress linearly reduced shoot dry matter, but seedlings of seeds from Montanhas showed smaller losses, despite having lower values at the potentials of -0.2 and $0 \mathrm{MPa}$ (Figure 4A).

The increment in salinity reduced shoot dry matter from the potentials of $-0.3 \mathrm{MPa}$ (Luziânia), $-0.2 \mathrm{MPa}$ (Vazante) and -0.2 $\mathrm{MPa}$ (Montanhas). Seedlings of seeds from Montanhas showed the lowest values of shoot dry matter for almost all levels of saline stress simulated, except at the potential of $-0.2 \mathrm{MPa}$ (Figure $4 \mathrm{~B}$ ).

In general, water stress (Figure $4 \mathrm{~A}$ ) was more harmful to shoot dry matter accumulation than saline stress (Figure 4B), since the reduction in this variable occurred already at the first potentials. It is important to highlight that the reduction in seedling shoot dry matter as a function of the decline in the osmotic potential of the solution is associated with the reduction in the speed of physiological and biochemical processes and the difficulty of hydrolysis and mobilization of reserves in the seeds, due to water deficit.

At the same time, salinity causes seed reserves, which could be used for embryo axis growth, to be used to repair cells affected by the excess of salts (Christovam et al., 2015).

For seedling root dry matter, there was an increment in the values at the first levels simulated with PEG, with highest values estimated at $-0.3 \mathrm{MPa}$, for the three regions, and decreasing values at more negative potentials (Figure $5 \mathrm{~A}$ ).
A.

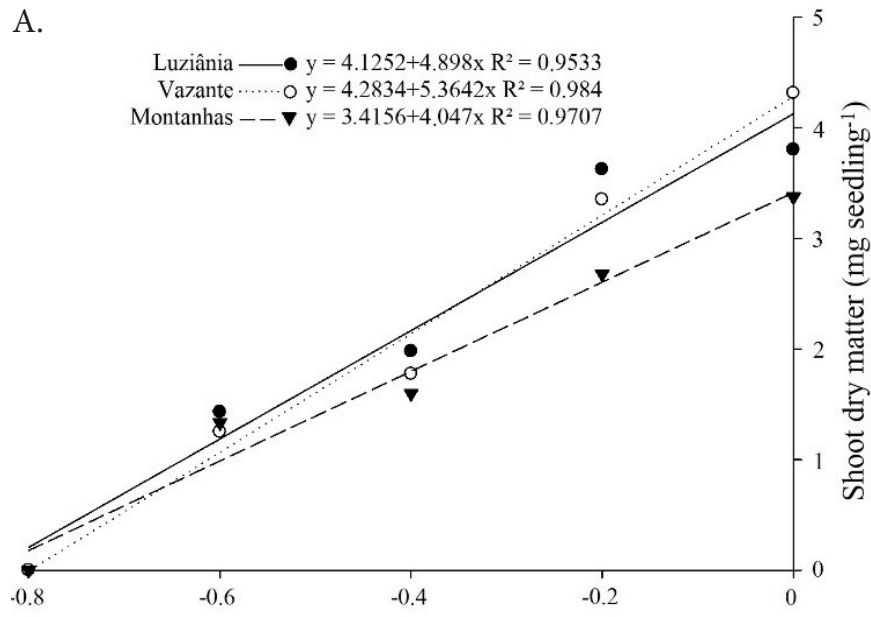

B.

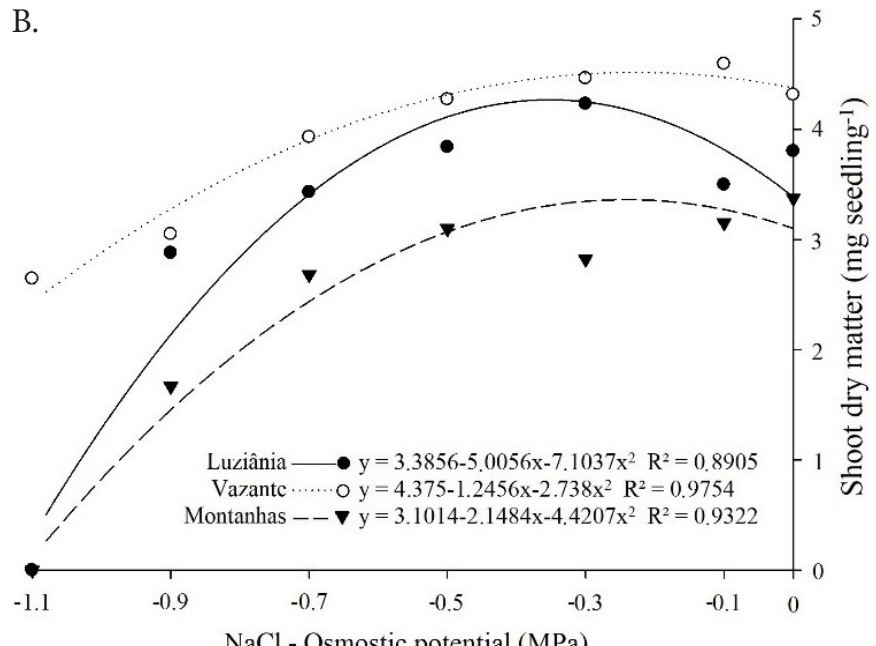

Figure 4. Shoot dry matter of Mimosa caesalpiniifolia Benth. seedlings as a function of different levels of water stress (A) and saline stress (B)

A.

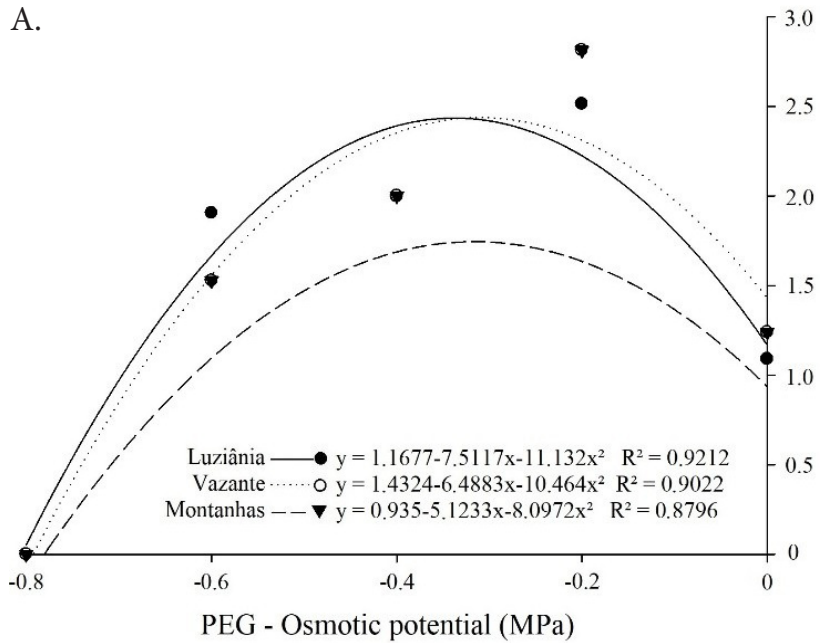

B.

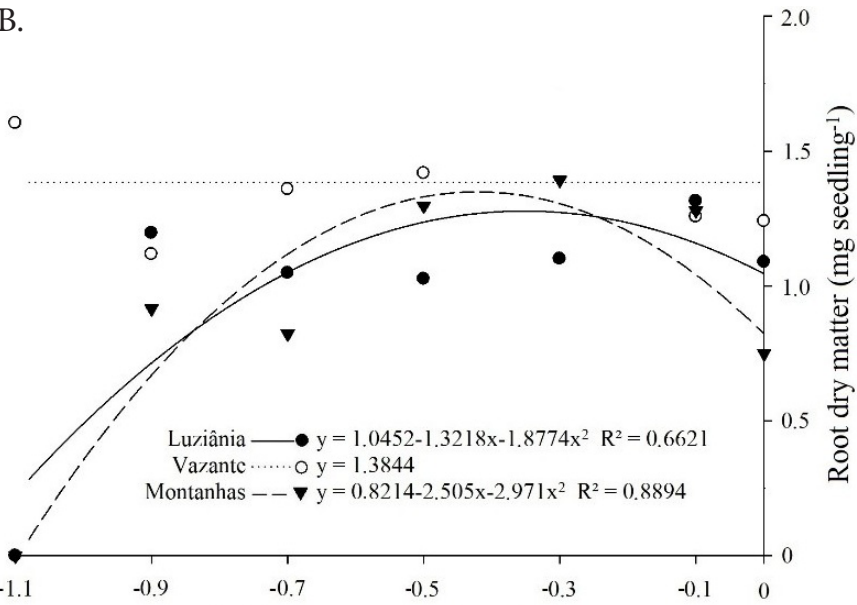

$\mathrm{NaCl}$ - Osmostic potential (MPa)

Figure 5. Root dry matter of Mimosa caesalpiniifolia Benth. seedlings as a function of different levels of water stress (A) and saline stress (B) 
Saline stress, on the other hand, had a limiting effect on seeds from Luziânia and Montanhas, from -0.9 MPa on, and the lowest values of root dry matter were found in seeds from Montanhas (Figure 5B).

Lower accumulation of root dry matter in the seedlings with the increment in water restriction induced by PEG solutions has also been found for Zizyphus joazeiro Mart. (Lima \& Torres, 2009), Amburana cearenses (Allemão) A.C. Smith (Almeida et al., 2014), Piptadenia moniliformis Benth. (Azerêdo et al., 2016) and Chorisia glaziovii O. Kuntze (Silva et al., 2016). Silva et al. (2009) observed reduction in shoot and root dry matter of M. caesalpiniifolia, when saline water (-0.04 to -0.2 $\mathrm{MPa}$ ) was used in irrigation. In another study with the same species, Sousa Neto et al. (2011) found that irrigation water salinity $(-0.02$ to $-0.2 \mathrm{MPa})$ led to reduction in height, stem dry matter and root dry matter of the seedlings.

The trend of increase in the root dry matter of the seedlings, observed at the first osmotic potentials induced by PEG, or of maintenance of these values, observed at the different potentials in the test with saline stress, may be an adaptive response that allows for higher tolerance to the osmotic retention of the solution, since larger root surfaces and extensions optimize water absorption (Christovam et al., 2015).

\section{Conclusions}

1. M. caesalpiniifolia seeds from different geographic regions showed a similar physiological response to water stress.

2. The tolerance to saline stress in M. caesalpiniifolia seeds varies according to the region of collection, and those from Vazante-MG were more tolerant during germination and initial growth of seedlings.

3. Osmotic stress induced by PEG 6000 causes more severe effects than that induced by $\mathrm{NaCl}$ on the physiological quality of M. caesalpiniifolia seeds.

\section{Literature Cited}

Almeida, J. P. N. de; Pinheiro, C. L.; Lessa, B. F. da T.; Gomes, F. M.; Medeiros Filho, S. Estresse hídrico e massa de sementes na germinação e crescimento de plântulas de Amburana cearensis (Allemão) A.C. Smith. Revista Ciência Agronômica, v.45, p.777787, 2014. https://doi.org/10.1590/S1806-66902014000400016

Azerêdo, G. A. de; Paula, R. C. de; Valeri, S. V. Germination of Piptadenia moniliformis Benth. seeds under water stress. Ciência Florestal, v.26, p.193-202, 2016. https://doi.org/10.5902/1980509821112

Bakke, I. A.; Freire, A. L. de O.; Bakke, O. A.; Andrade, A. P. de; Bruno, R. de L. A. Water and sodium chloride effects on Mimosa tenuiflora (Willd.) poiret seed germination. Revista Caatinga, v.19, p.261-267, 2006.

Barreto, H. B. F.; Freitas, R. M. O. de; Oliveira, L. A. de A.; Araújo, J. A. de M.; Costa, E. M. da. Efeito da irrigação com água salina na germinação de sementes de sábia (Mimosa caesalpiniifolia Benth). Revista Verde de Agroecologia e Desenvolvimento Sustentável, v.5, p.125-130, 2010.

Botezelli, L.; Davide, A. C.; Malavasi, M. M. Características dos frutos e sementes de quatro procedências de Dipteryx alata Vogel (Baru). Cerne, v.6, p.9-18, 2000.
Brasil. Ministério da Agricultura, Pecuária e Abastecimento. Instruções para análise de sementes de espécies florestais. Brasília: Secretaria Nacional de Defesa Agropecuária, Brasília: MAPA/ ACS, 2013. 98p.

Christovam, M. C.; Silva, T. L. da; Yamamoto, C. J. T.; Moreira, A. L. de L.; Custódio, C. C.; Pacheco, A. C.; Abrantes, F. L. Germinação e desenvolvimento inicial de plântulas de cultivares de Urochloa brizantha em condições de estresse hídrico. Informativo Abrates, v.25, p.43-49, 2015.

Guedes, R. S.; Alves, E. U.; Viana, J. S.; Gonçalves, E. P.; Lima, C. R. de; Santos, S. do R. N. dos. Germinação e vigor de sementes de Apeiba tibourbou submetidas ao estresse hídrico e diferentes temperaturas. Ciência Florestal, v.23, p.45-53, 2013. https://doi. org/10.5902/198050988438

IUCN - International Union for the Conservation of Nature Red List of Threatened Species. Version 2016.1. Downloaded on: Jul. 2017.

Lima, B. G. de; Torres, S. B. Estresses hídrico e salino na germinação de sementes de Zizyphus joazeiro Mart. (Rhamnaceae). Revista Caatinga, v.22, p.93-99, 2009.

Lorenzi, H. Árvores brasileiras: Manual de identificação e cultivo de plantas arbóreas nativas do Brasil. 5.ed. São Paulo: Instituto Plantarum, 2008. 201p.

Maguire, J. D. Speed of germination-aid in selection and evaluation for seedlings emergence and vigor. Crop Science, v.2, p.176-177, 1962. https://doi.org/10.2135/cropsci1962.0011183X000200020033X

Moura, M. R.; Lima, R. P.; Farias, S. G. G. de; Alves, A. R.; Silva, R. B. e. Efeito do estresse hídrico e do cloreto de sódio na germinação de Mimosa caesalpiniifolia Benth. Revista Verde de Agroecologia e Desenvolvimento Sustentável, v.6, p.230-235, 2011.

Nasr, S. M. H.; Parsakhoo, A.; Naghavi, H.; Koohi, S. K. S. Effect of salt stress on germination and seedling growth of Prosopis juliflora (Sw.). New Forests, v.43, p.45-55, 2012. https://doi.org/10.1007/ s11056-011-9265-9

Pereira, M. R. R.; Martins, C. C.; Souza, G. S. F.; Martins, D. Influência do estresse hídrico e salino na germinação de Urochloa decumbens e Urochloa ruziziensis. Bioscience Journal, v.28, p.537-545, 2012.

Ribeiro, M. C. C.; Barros, N. M. S.; Barros Júnior, A. P.; Silveira, L. M. da. Tolerância do sabiá (Mimosa caesalpiniaefolia Benth.) à salinidade durante a germinação e o desenvolvimento de plântulas. Revista Caatinga, v.21, p.123-126, 2008.

Salysbury, F. B.; Ross, C. W. Plant physiology. 4.ed. Belmont: Wadsworth Publishing Company, 1992. 682p.

Santos, C. A. dos; Silva, N. V. da; Walter, L. S.; Silva, E. C. A. da; Nogueira, R. J. M. C. Germinação de duas espécies da caatinga sob déficit hídrico e salinidade. Pesquisa Florestal Brasileira, v.36, p.219-224, 2016. https://doi.org/10.4336/2016.pfb.36.87.1017

Silva, F. de A. S. e; Azevedo, C. A. V. de. O Software Assistat Versão 7.7 e sua utilização na análise de dados experimentais. African Journal of Agricultural Research, v.11, p.3733-3740, 2016. https:// doi.org/10.5897/AJAR2016.11522

Silva, M. B. R. da; Viégas, R. A.; Dantas Neto, J.; Farias, S. A. R. Estresse salino em plantas da espécie florestal sabiá. Revista Caminhos de Geografia, v.10, p.120-127, 2009.

Silva, M. L. M. da; Alves, E. U.; Bruno, R. de L. A.; Moura, S. da S. S.; Santos Neto, A. P. dos. Germinação de sementes de Chorisia glaziovii O. Kuntze submetidas ao estresse hídrico em diferentes temperaturas. Ciência Florestal, v.26, p.999-1007, 2016. https:// doi.org/10.5902/1980509824229 
Silva, P. S. L.; Dias, P. C.; Oliveira, V. R. de; Potencial do sabiá como cultura do semiárido. Mossoró: EDUFERSA, 2015. 264p.

Sousa Neto, O. N. de; Dias, N. da S.; Ferreira Neto, M.; Lira, R. B. de; Rebouças, J. R. L. Utilização do rejeito da dessalinização da água na produção de sementes de espécies da Caatinga. Revista Caatinga, v.24, p.123-129, 2011.
Taiz, L.; Zeiger, E. Fisiologia vegetal. 5.ed. Porto Alegre: Artmed, 2013. 954p.

Vilella, F. A.; Doni Filho, L.; Siqueira, E. L. Tabela do potencial osmótico em função da concentração de polietileno glicol 6000 e da temperatura. Pesquisa Agropecuária Brasileira, v.26, p.19571968, 1991. 